\title{
Africa Current Issues
}

\section{The CFA Franc:}

\section{A Currency by Any Other Name?}




\section{The CFA Franc: A Currency by Any Other Name?}

As 2019 drew to a close, West Africa's Economic and Monetary Union (WAEMU) and France announced the renaming of the CFA Franc - their common currency - as the Eco ${ }^{1}$. The announcement elicited responses ranging from excitement and anticipation to confusion and anger. Anglophone member states ${ }^{2}$ of the ECOWAS (Economic Community of West African States), having announced plans to adopt a common currency unit of the same name, were caught off-guard. ${ }^{3}$

The new Eco currency regime, like its predecessor, will be pegged to the Euro. However, countries using the new currency no longer need to maintain $50 \%$ of their foreign exchange reserves on deposit with the French Treasury, and France will lose its board membership on the Central Bank of West African States (BCEAO). It is hoped that these measures will allow a greater degree of fiscal and monetary policy autonomy and stimulate growth. Beyond these changes, the path forward for the Eco and its adopters is worryingly opaque.

The announcement lacked clarity, both on practical and symbolic issues. What role would the new currency play? When would it become operational? How would it roll out (likely 2H20)? Was it a pragmatic step in severing colonial ties or merely political optics designed to garner populist support? Did the move open a new chapter in Francophone / Anglophone and Francophone / French relations? With so many questions unanswered, investors do now know what to make of the Eco, or how to prepare for it. What could have been a landmark for the region has instead become a source of confusion, mistrust and apathy.

Overcoming uncertainty is the biggest challenge to the Eco's shaky start: this decision has wide ranging implications that extend well beyond the currency. The Eco has the potential to impact trade and regulatory agreements and the investment climate in the region.

This article unpacks five key questions:

1. Is this move merely cosmetic, or is there more than meets the eye?

2. What does the new Eco mean for regional monetary policy and its independence?

3. How might the Eco impact trade and other relations among WAEMU and France and Anglophone ECOWAS states, and what are the potential benefits and risks for business?

4. Can political will and economic consensus within the region hold and improve its bargaining and political position, or could divergent interests potentially lead to economic fallout amongst members?

5. Where to from here and what might the next decade look like for the Eco?

Understanding these factors will be critical for businesses wishing to successfully navigate the shifting terrain and relationship with Europe. Proposed changes to common currency regimes, currently relatively benign, may in future either accelerate development, or lead to hyperinflation and economic ruin.

\section{THE CFA franc explained - a brief background}

The CFA (Financial Community of Africa) franc is the common currency of the 14 African member countries of the Franc-Zones of central and west Africa. It was created 1945 and implemented to cushion the French colonies against volatile post-war currency swings.

At the time, then French Finance Minister, René Pleven explained France's rationale in deeply altruistic terms: 
"In a show of her generosity and selflessness, metropolitan France, wishing not to impose on her faraway daughters the consequences of her own poverty, is setting different exchange rates for their currency. ${ }^{\text {" }}$

Pegged at a fixed rate to the French franc ( 1 Euro $=656$ CFA Franc) and later the Euro after the formation of the Eurozone, the CFA franc is used by $8^{1}$ states from the West Africa's Monetary Union (WAEMU) overseen by the Central Bank of West African States (BCEAO) and $6{ }^{1}$ from the Economic and Monetary Community of Central African States (CEMAC). The combined GDP of CFA participants amounts to $\$ 235$ billion and a population of 155 million people $-12 \%$ of the Africa's GDP and $14 \%$ of its population according to the IMF. There has been persistent distrust of the CFA and resentment over its colonial legacy.

On 21 December 2019, Ivorian President Alassane Ouattara and his French counterpart Emmanuel Macron announced that the CFA will from mid-2020, be known as the Eco, in part, to loosen historical ties with France (19). For now, there are very few changes to the structure of the tender agreement, but it seems further changes are inevitable in years to come. The new currency will only be adopted by the 8 WAEMU countries currently trading the CFA franc.

Over its nearly 75 year history, the CFA has been a polarising political and economic force. Proponents of the common currency argue that it has shielded the CFA zone from the economic instability runaway inflation would have precipitated. Its peg and convertibility to the Euro lends the countries' currency credibility and monetary predictability. This in turn facilitates smooth goods and services trade between Europe and the currency bloc, and the generation of much needed export revenue.

Critics see the Franc as an imposed mechanism through which its former colonial masters exercise economic and monetary control while profiting from their foreign exchange deposits. They argue that the lack of policy autonomy use of the Franc ensures is holding back economic stimulus measures that could propel the zone to a higher growth and development trajectory.

The move to the Eco is the first real test in loosening monetary relations between France and the Francophone region.

\section{Is this move merely cosmetic, or is there more than meets the eye?}

There appear to be few material differences between the CFA Franc and the Eco beyond the name change. Indeed several of the Franc's most controversial attributes remain untouched: the new currency will remain pegged to the Euro and France will continue guaranteeing unlimited conversion of the CFA to Euros. The primary differences are related to governance: foreign exchange reserves need no longer be deposited with the French Treasury ${ }^{5}$, and the French will no longer be represented on the BCEAO Monetary Policy Committee (See Table 1).

Table 1: Currency regime comparison

\begin{tabular}{|c|c|c|}
\hline Currency & CFA Franc & Eco \\
\hline Currency & Pegged to Euro & Pegged to Euro \\
\hline $\begin{array}{c}\text { Convertibility of CFA Franc to } \\
\text { Euro }\end{array}$ & Unlimited and guaranteed & $0 \%$ \\
\hline $\begin{array}{c}\text { Minimum FX Reserve Deposit } \\
\text { with French Treasury }\end{array}$ & $50 \%$ & No \\
\hline $\begin{array}{c}\text { French representation on BCEAO } \\
\text { MPC }\end{array}$ & Yes & BCEAO free to seek higher yield \\
\hline Interest on FX reserve deposits
\end{tabular}

Source: BCEAO 
Kristalina Georgieva, the Managing Director of the International Monetary Fund (IMF) said of the changes:

"They constitute a key step in the modernization of long-standing arrangements between the West African Economic and Monetary Union and France. The reforms also maintain key elements of stability that have served the region well, including the fixed exchange rate with the euro and the guarantee of unlimited convertibility provided by France".

The IMF stressed the importance of maintaining the agreement's status quo. Georgieva's comments hint at concerns that greater policy autonomy could lead to economic recklessness and instability. Proponents of the CFA argue that the common currency protects members against irresponsible governments prone to populist monetary and fiscal policy. Even so, many of the WAEMU countries already receive IMF assistance and may soon be joined by others in the event of severe fiscal and monetary deterioration.

Detractors, however, have long railed against French influence ${ }^{6}$ on the currency and the region's monetary and economic policy, whether real or perceived. ${ }^{7}$ They accuse France of monetary imperialism ${ }^{8}$ and of maintaining the CFA in order to undermine country sovereignty and maintain a stranglehold over member economies. ${ }^{9}$ Economics professor Mamadou Koulibaly is an outspoken critic:

"The CFA franc is financially repressive, unfair, and morally indefensible."

The revamped CFA does not fundamentally address these grievances on a practical level and explains the initial cynicism, with many viewing the Eco merely as a cosmetic makeover or symbolic gesture designed to quell anti-French sentiment ${ }^{10}$. Maintaining the Euro peg and guaranteed convertibility by France keeps in place the dependence on French authorities ${ }^{11}$. In the eyes of economist, Felwine Sarr, as with many others:

"...this reform ... only concerns the most symbolic aspects, but leaves major components of the former relationship unchanged."

The power of the symbolism should not be dismissed. Both parties acknowledge that the pending switch is only a precursor to greater sovereign and economic independence and a start at undoing colonial entanglement ${ }^{12}$. At the announcement of the Eco, Macron said:

"... too often today, France is literally perceived in terms of domination and the trappings of colonialism that did exist. Which was a profound error. A fault of the French Republic,"

- President Emmanuel Macron

As such, France can claim to be making amends for its historical wrongs, while WAEMU countries can assert to be actively shaking off their colonial legacy for which both sides gain significant political capital. Rather than being an actual economic game changer for French and Francophone Africa relations, the Eco must instead be viewed as emblematic of the direction in which real-world relations are likely to shift - a gradual loosening of economic and monetary ties between the two blocs akin to handholding. This in itself is seen as patronising.

There are, nevertheless some concessions from France that will begin facilitating this transition to greater autonomy, such as relinquishing direct and overt French influence on monetary policy (by not having a French representative on the MPC), and allowing WAEMU countries to deposit FX reserves in other economies.

\section{What does the Eco mean for monetary policy and its independence?}

In short, and in the short-term at least, it means very little. Changes under the Eco do not meaningfully add to the policy options available to the BCEAO, who while using a French backed currency, remain beholden to orthodox and conservative monetary and fiscal convention. The sole policy of the BCEAO 
is that of maintaining price stability. Growth, as with most central banks, is beyond their scope of influence.

The Euro currency peg has historically sheltered WAEMU countries from far higher levels of inflation than some of their African counterparts, and has even been called the most stable monetary union in the world ${ }^{13}$. Excluding hyperinflation events in Angola and Zimbabwe, inflation in CFA franc countries has averaged 4 percentage points (pps) lower than the rest of Africa over the past two decades (see figure 1).

Figure 1: West Africa CFA country CPI vs. Africa average CPI

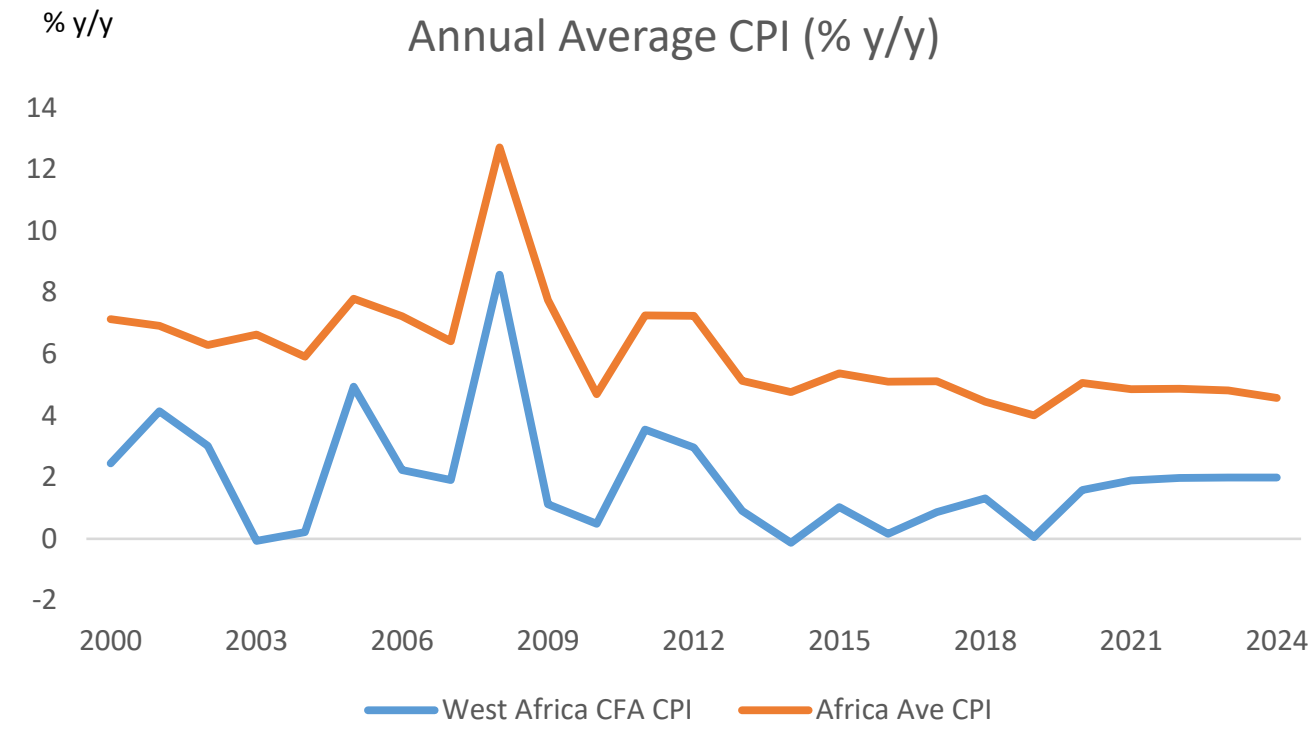

Source: World Economic Outlook ${ }^{14}$

Such price stability is key not only in maintaining the purchasing power of citizens, and in turn sustaining social stability, but it also makes foreign exchange risk between CFA franc countries and the Eurozone negligible ${ }^{15}$. Importantly, it allows the countries to maintain steady and predictable interest rates, and certainty is an investor's greatest ally. ${ }^{16}$

Euro strength relative to a basket of major global currencies, however, means that the CFA is significantly overvalued relative to the bloc's fiscal metrics and economic growth profile. By implication, countries and exporters are not able to get the full value a floating (fair value) currency would allow, thereby disincentivising investment and expansion in productive capabilities. Conversely, imports which now come predominantly from China, India and other African countries (the CFA was designed to facilitate intraregional WAEMU trade and trade with France) become comparatively expensive. ${ }^{17}$ The result is a mismatch between incoming revenue from exports and outgoing funds used to pay for imports - current account deficits which hover at around $4 \%$ of WAEMU country GDP (See figure 2). 
Figure 2: West Africa CFA country current account balance as \% of GDP

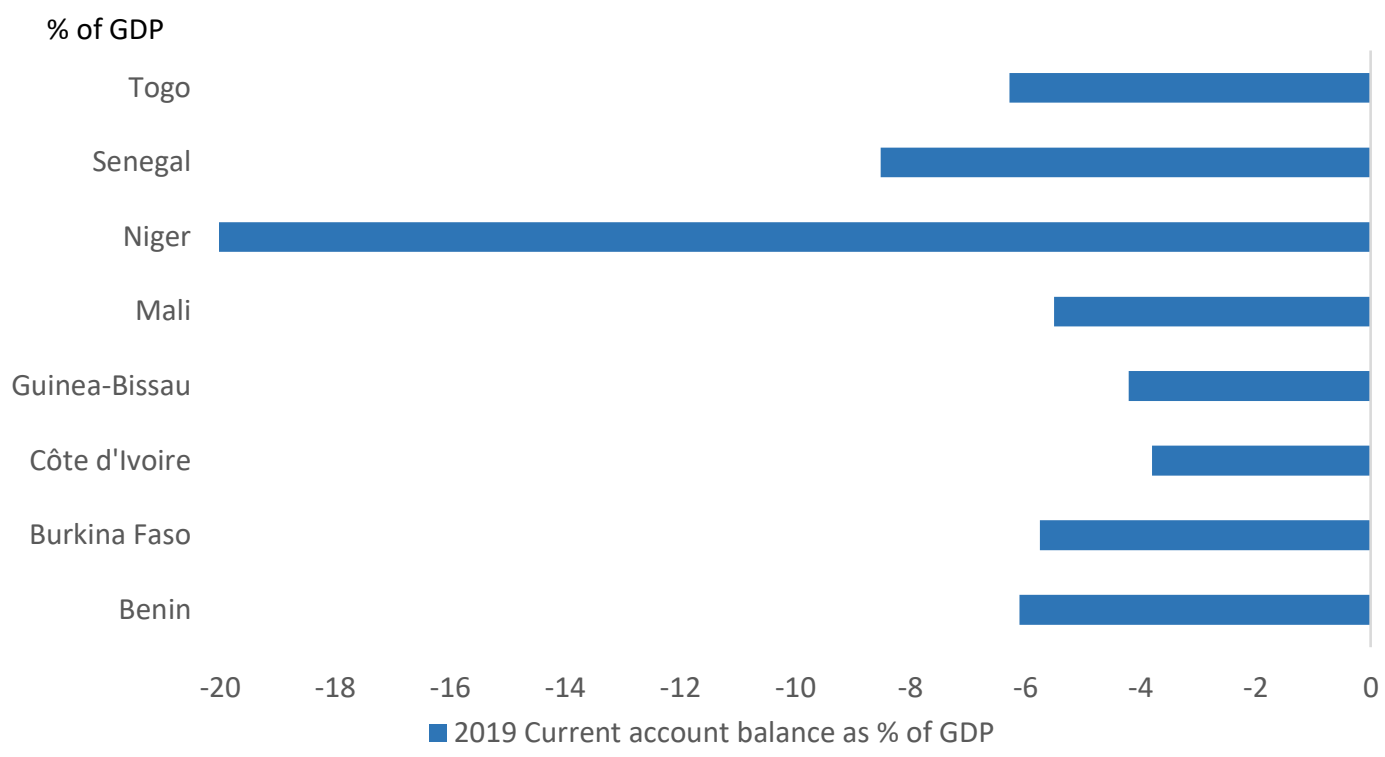

Source: World Economic Outlook ${ }^{18}$

Ordinarily, a floating currency would weaken as deficit widened and strengthen as it narrowed. This would act as a natural shock absorber for deficits, enabling equilibrium by stimulating exports and curbing imports. The Euro peg negates this. It also keeps inflation artificially low leaving the monetary policy committee with little in the way of policy responses to hike rates to allow the current account to balance. Moreover, even if the MPC's mandate was changed to include growth, rates can't be materially lowered to stimulate growth, as this move would only exacerbate the deficit margin. The WAEMU's MPC is therefore left impotent; with nothing more to do than follow interest rate movements in the Eurozone.

This raises another bone of contention around the foreign exchange reserve requirement. CFA critics charge that France profited from African money deposited with the French Treasury. This they say was done by France using the money to invest in high yielding instruments while only paying WAEMU states exceptionally low interest rates, and keeping the difference as profit. France denies this. To add insult to injury, WAEMU countries can't use the FX reserves as collateral to raise debt since France already encumbers them for guarantee purposes. ${ }^{19}$

More recently though, exceptionally low interest rates in developed markets (DMs) means that the interest earned on FX reserves is not keeping pace with WAEMU inflation, and that FX reserve funds are actually shrinking in real terms. Further, as rates enter negative territory, WAEMU states would effectively be paying France to hold their deposits.

There are no definitive deposit rules under the Eco available in the public domain save for no longer being compelled to deposit 50\% with French Treasury. Some suggest that money can now be deposited with any Eurozone Treasury, while others contend that any sovereign treasury can be used. If it is the former, there will be no discernible difference from the Franc scenario, but the latter opens the possibility of WAEMU members being free either to draw down those reserves or seek more favourable deposit terms in higher yielding economies, all while maintaining the inflation protection offered by the currency peg.

Currently, WAEMU countries have approximately USD 12 billion on deposit with the French central bank. This money can now be invested in central banks offering far higher real interest rates. What makes this even more attractive is that these countries have exceptionally low inflation, shielded by the 
Euro currency peg, implying the real rate of return from higher yielding deposits could be substantially greater.

The interest accrued could prove a large, positive fiscal tailwind for CFA countries, who could then draw down funds (or just the interest) to spur economic development and employment, all the while being backed by the French Treasury. This would also go some way in addressing the fiscal imbalances (see figure 3).

Figure 3: West Africa CFA country primary balance as \% of GDP

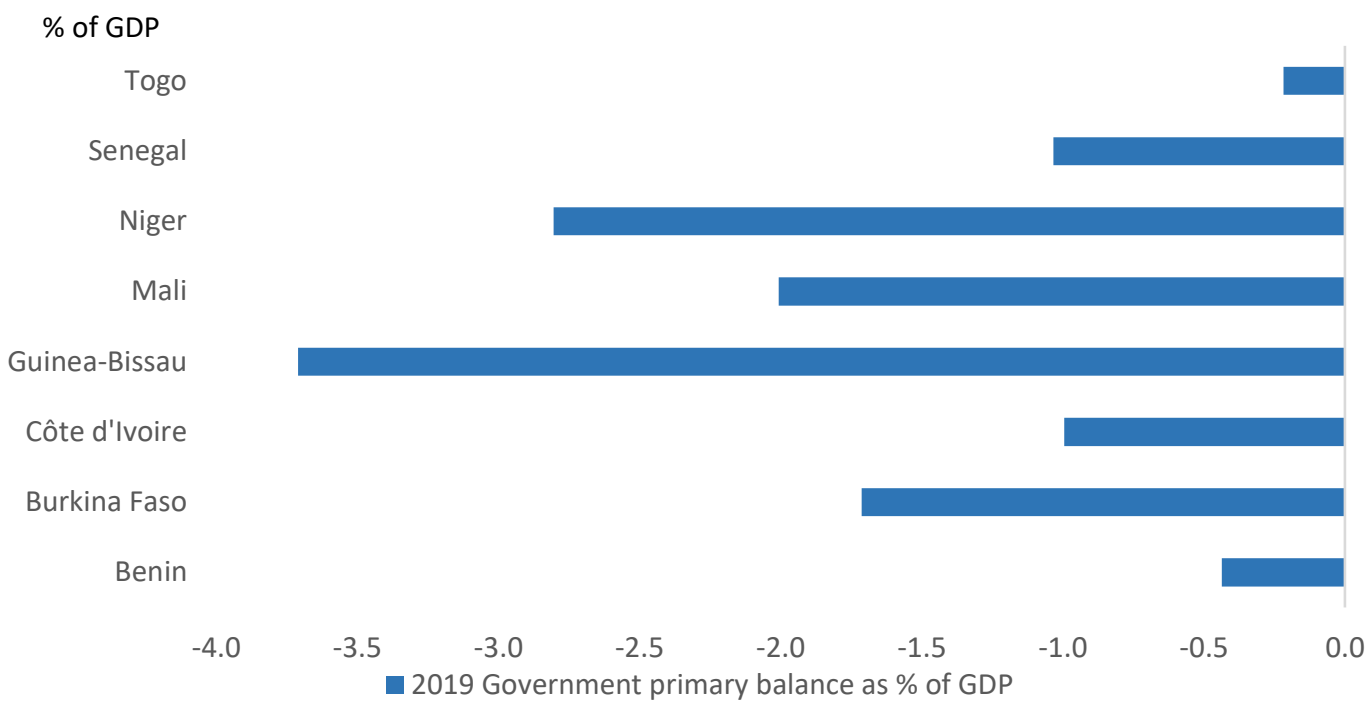

Source: World Economic Outlook ${ }^{20}$

The Eco also comes at a time when African countries will begin trading under the African Continental Free Trade Agreement (AfCFTA), under which the movement of goods and services between African countries would be exempt from duties. Additional financial flexibility under the Eco, coupled with a significant cost reduction on duties could be a massive boon for CFA countries, and allow far faster economic growth if prudently implemented.

Ultimately, there is no quick fix for a move away from French ties; a gradual loosening of relations is the most responsible path for transitioning to monetary and economic independence. CFA countries have neither the track record nor fiscal strength to swiftly decouple from French support and withstand a rapid depreciation of an independent currency. Mali's exit from the CFA zone ${ }^{21}$ in 1962 serves as a warning. Shortly after, the country embarked on an expansionist monetary policy path, leading to massive devaluation, social unrest and eventually a coup. ${ }^{22}$

To some extent, monetary and economic policy in CFA countries is stuck in limbo under the current regime. Under French support, they won't suffer currency ruin and hyperinflation but without a currency able to shift according to market dynamics, they will not experience far higher growth rates.

What these countries choose to do with their newfound options, will make the difference between rapidly accelerating development and investment and economic catastrophe.

\section{What is the impact on WAEMU relations with France and Anglophone CFA countries?}

The political and economic terrain surrounding the CFA Franc is exceedingly complex, colonial legacy issues aside. It is nevertheless quite conceivable that the move to the Eco, designed at least symbolically to begin loosening monetary ties between France and WAEMU, may engender a sense of redress and goodwill in the longer term and foster greater trade and investment opportunities. This 
would neatly align with Macron's hope for a fresh start to relations with CFA franc economies in order to cement the country's already extensive presence and influence on the continent, particularly as European growth slows and African growth is set to accelerate. The outlook over the medium term is more opaque.

Despite trade and investment in WAEMU countries having been on the increase, regional imports have consistently outstripped exports by an increasing margin, leading to a growing, and in time, unsustainable trade deficit along with inevitable fiscal implications (see figure 4).

Figure 4: WAEMU exports vs. imports

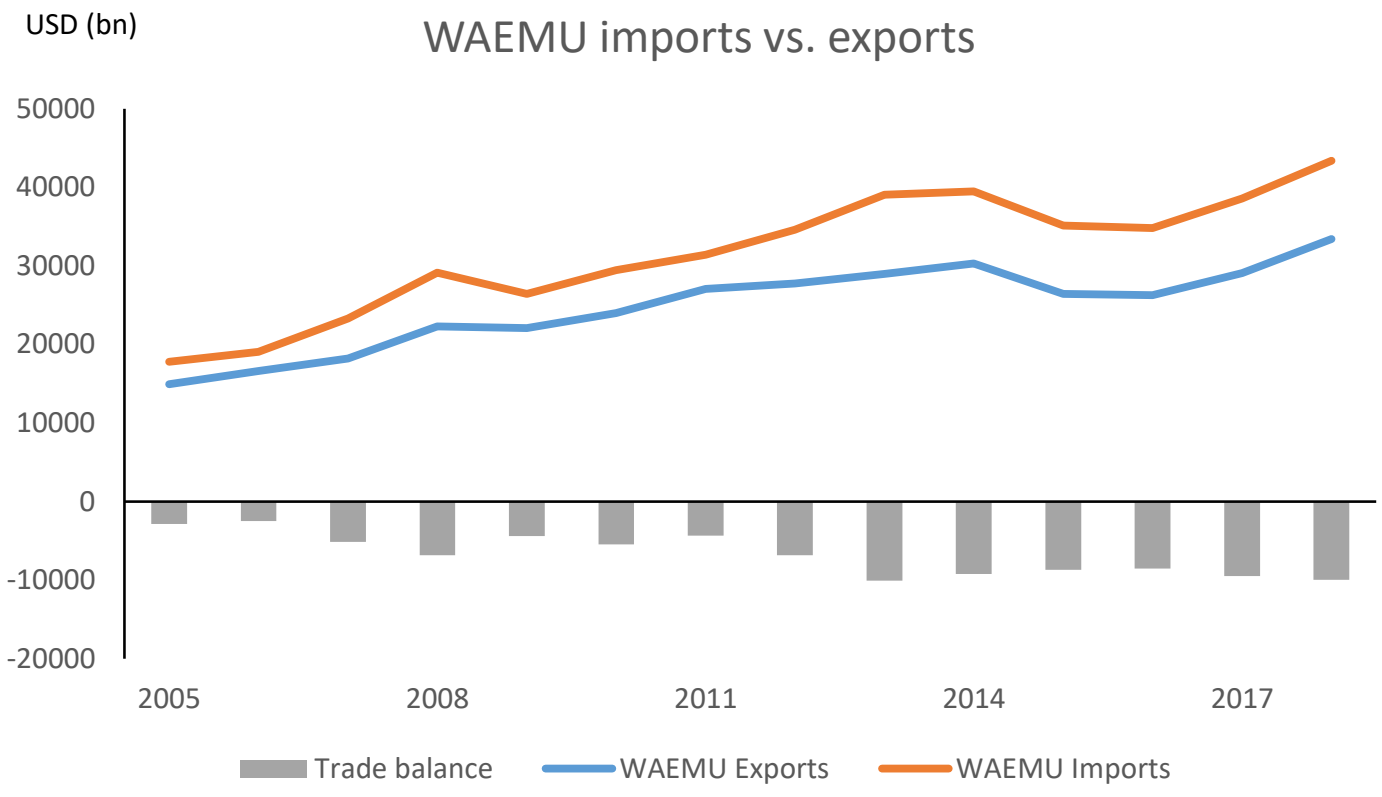

Source: UNCTAD

More broadly, the structural rigidities of the currency peg, which was set up to facilitate trade with France have not evolved to take into account the rising trade prominence of economies from the East such as China, who now account for a far greater percentage of both WAEMU imports and exports.

The same principle applies to foreign direct investment. While inward FDI has grown appreciably (figure 5), current growth rates could have easily been exceeded in a more liberally managed currency regime, where a weaker Franc would give investors more "bang for their buck" as compensation for the risk premium. As it stands, the region's relative Euro parity makes investment expensive, and a deterrent to more meaningful foreign interest. 
Figure 5: WAEMU inward FDI flow

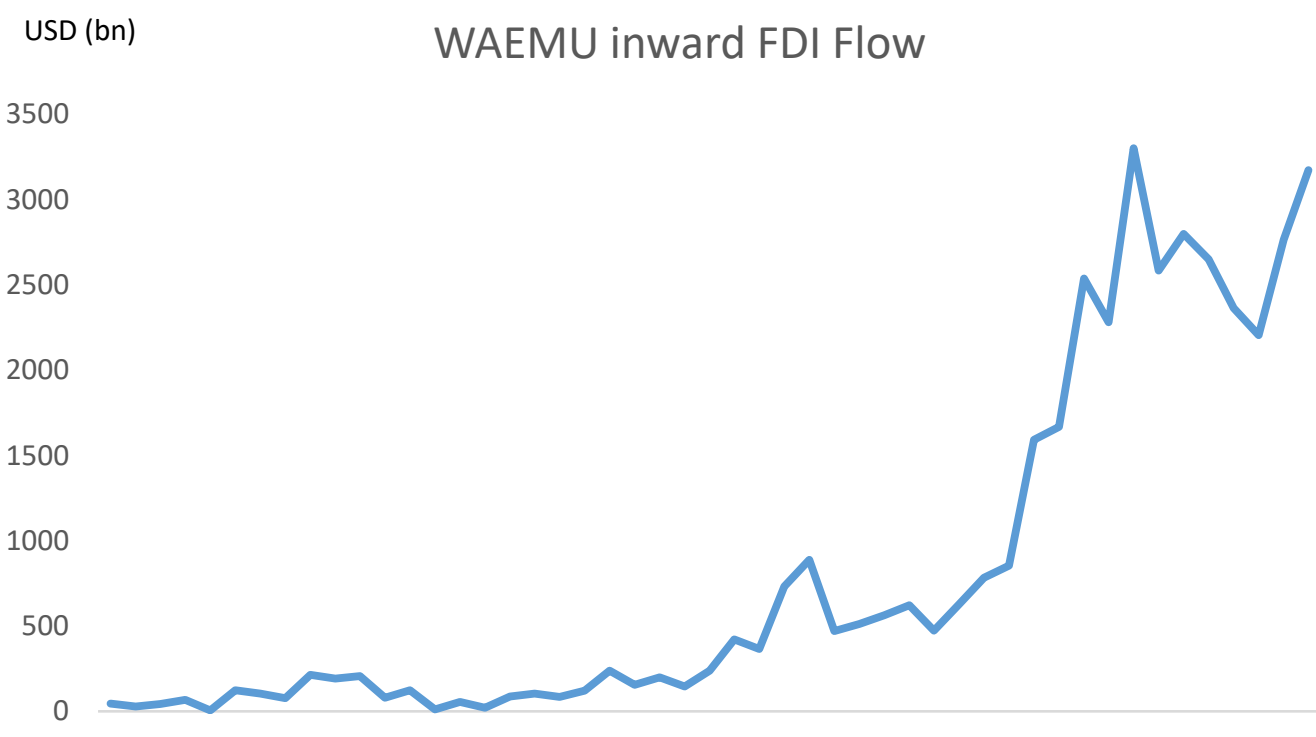

19701973197619791982198519881991199419972000200320062009201220152018

WAEMU (West African Economic and Monetary Union)

Source: UNCTAD

Where it has provided support is at an intraregional trade and investment level, not just within WAEMU, but with Anglophone ECOWAS members - WAEMU and CEMAC areas share the same currency peg to the Euro and are interchangeable. The level of trade and investment between these two blocs, however, is insufficient to compensate for contained trade and investment growth from larger economic zones.

One potential unintended consequence of the freshly announced Eco and the lack of clarity surrounding many of its nuances is that foreign investors are likely to hold off on entering the market until greater detail and certainty emerges.

For all the talk of loosening the hold of France to facilitate faster growth and attract foreign investment, structural reform should be of more immediate concern to WAEMU countries. Many of the needed measures will be relatively easy to implement. This economic bloc fares exceptionally poorly on the World Bank's Ease of Doing Business Index in almost every category (see figures 6 and 7).

Figure 6 and 7: WAEMU inward FDI flow
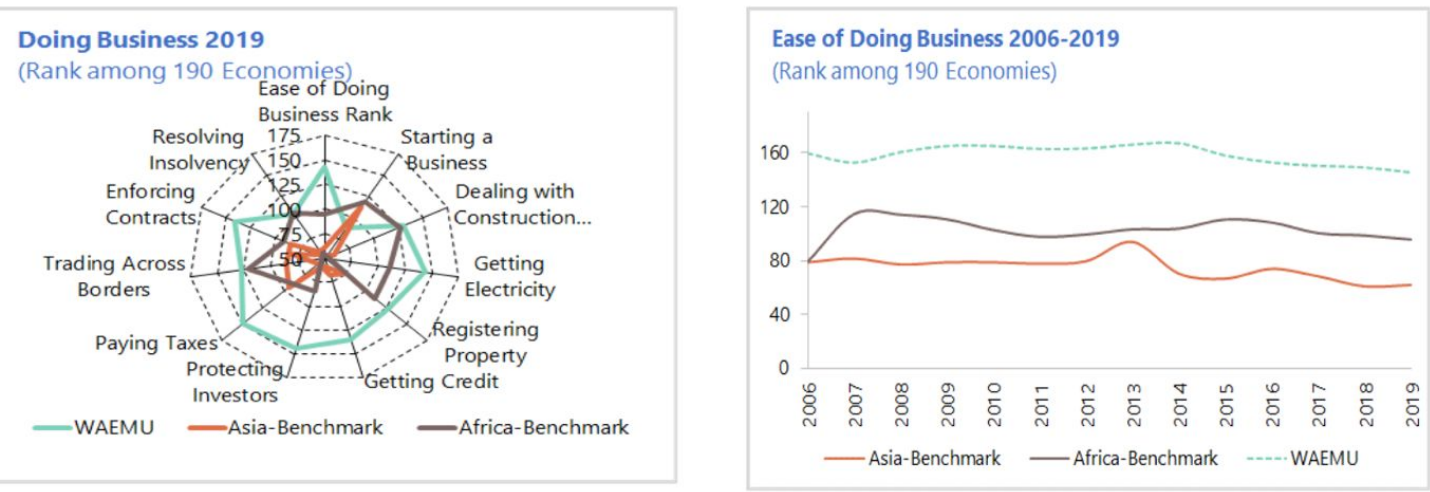

Source: World Bank 
Addressing infrastructure backlogs and bottlenecks while simultaneously improving the business environment through sound and stable policy would go a long way at increasing business confidence and attracting investment. Such measures would enable faster economic growth and lay a sound foundation for withstanding the headwinds associated with greater monetary and fiscal policy flexibility.

Accurately predicting the impacts, opportunities and risks likely to emerge from WAEMU's adoption of the Eco is difficult, given the lack of clarity and the fact that fundamentally, not much has changed. Key developments business should be on the lookout for include:

Table 2: Regional risk assessment

\begin{tabular}{|c|c|c|}
\hline Sector & Impact & Comment \\
\hline $\begin{array}{l}\text { Monetary policy - } \\
\text { Interest rates }\end{array}$ & Neutral & $\begin{array}{l}\text { Monetary policy constrained by Eurozone inflation, not French } \\
\text { influence. Possible that the BCEAO may opt to cut modestly, } \\
\text { but inflation is already low, and quantum of cuts likely } \\
\text { negligible. }\end{array}$ \\
\hline Fiscal policy & $\begin{array}{l}\text { Initially } \\
\text { positive }\end{array}$ & $\begin{array}{l}\text { Budgets likely to be more expansionary given additional fiscal } \\
\text { headroom from FX reserve deposits. Expenditure may improve } \\
\text { marginally but sustainability dependent on prudent } \\
\text { management - corruption or allocations to recurrent spending } \\
\text { will see a sharp reversal over the medium term. }\end{array}$ \\
\hline Investment & $\begin{array}{l}\text { Initially } \\
\text { positive }\end{array}$ & $\begin{array}{l}\text { Infrastructure investments will create opportunities for the } \\
\text { private sector (manufacturing, construction, engineering) in } \\
\text { turn attracting foreign investors - boost to investor sentiment. } \\
\text { Populist spending will have the opposite effect. Significant } \\
\text { regulatory reform required to truly unlock sustainable growth. }\end{array}$ \\
\hline Trade & Neutral & $\begin{array}{l}\text { Eco remains pegged to the Euro and unlikely that trade will } \\
\text { improve meaningfully. Danger lies in trade retaliation from } \\
\text { WAMZ and } \\
\text { CEMAC countries (additional tariffs or outright trade bans with } \\
\text { WAEMU region) - far reaching negative implications. }\end{array}$ \\
\hline Domestic economy & $\begin{array}{l}\text { Initially } \\
\text { positive }\end{array}$ & $\begin{array}{l}\text { Growth will likely benefit modestly from short-term fiscal } \\
\text { tailwinds, but danger of populist spending ever present, } \\
\text { particularly ahead of regional elections (longer-term growth } \\
\text { negative). }\end{array}$ \\
\hline French relations & Neutral & $\begin{array}{l}\text { France's extensive presence and interest in the region will see } \\
\text { political relations remain cordial despite looser economic } \\
\text { influence. }\end{array}$ \\
\hline Ecowas relations & Negative & $\begin{array}{l}\text { WAMZ members of ECOWAS likely to retaliate against } \\
\text { WAEMU's unilateral decision to adopt Eco. Some form of } \\
\text { sanction (trade) or splintering a rising possibility. }\end{array}$ \\
\hline
\end{tabular}

\section{Key take-aways for business}

The prevailing climate of market uncertainty regarding implementation details is likely to generate investor unease. While fiscal loosening may boost investor confidence in the short term, and might even 
attracting foreign investor interest, currency inflexibility remains an investment barrier. The currency market remains inelastic, with interest rates movements aligned to EU trends.

The proposed shared currency regime potentially has different impacts on specific sectors. Populist policies would provide a short-term boost for consumption, but will have negative long-term effects for the entire economy across all sectors. A positive spinoff will be felt in retail and services sectors, through higher employment. Construction and engineering firms may benefit, if policy prioritizes infrastructure.

The impact on trade is likely to be negligible, given the lack of tangible change in currency mechanics. There will be no boost from a weaker Eco, which would support the export sector.

The downside potential is trade retaliation or sanctions from disgruntled WAMZ countries that have extensive clout and strong trade relations in the region. There is a risk of broader fallout in the West Africa region is escalating ahead of AfCFTA trade commencement.

From an overall perspective, the Eco might lead to a more expansionary but not necessarily growth sustaining fiscal agenda. However, it may ultimately be negative for the Eco economy as WAMZ / CEMAC countries are significant trade partners, more so than France - intraregional trade is a critical revenue generator for WAEMU.

\section{Can political will and economic consensus within the region hold or will divergent interests lead to economic fallout?}

Political disunity is the greatest obstacle to the successful implementation of the Eco and a broader rollout to the CEMAC region. Six members of ECOWAS ${ }^{23}$ (West African Monetary Zone or WAMZ) had been planning the formation of a common currency since $2000^{24}$, also set to have been called the Eco, which would have eventually merge with the CFA Franc. France and WAEMU's announcement of their own version of the Eco threw the cat among the pigeons and should not be seen as a precursor to this strategy.

Nigeria has already voiced strong opposition to the WAEMU Eco ${ }^{25}$, even calling for an extraordinary summit of WAMZ to discuss a response. Nigeria was clearly caught off-guard by the announcement and fears the move is a political ploy by France to exclude Africa's largest economy from extending any further influence in France's former territories.

The confrontation pits WAEMU against WAMZ (both part of ECOWAS) with CEMAC looking on and already having expressed interest in joining WAEMU's Eco. ${ }^{26}$ The real battle, however, is between Nigeria and France. Any splintering of ECOWAS, whose largest and most influential member is Nigeria, would be disastrous for West African unity and the promises offered by AfCFTA.

\section{Where to from here and what will the next decade look like for the Eco?}

It is clear from the manoeuvring that economic pragmatism will take a back seat to political power plays. The friction created immediately casts doubt on the entire endeavour of a single West African currency, which was always bound to be hobbled by economic practicalities (relative sizes and composition of individual economies) even without any political wrangling. With punches having been thrown before the bell has sounded, it appears unlikely that there will be sufficient consensus to realise regional and continental integration and it is too early to get excited about a single West African currency.

Hard lessons have been learnt by WAEMU countries when the CFA was devalued in $1994^{27}$ and the risk event still looms over ties to the French. A measured devaluation could actually stimulate the export sector and boost growth but a repeat of 1994 would devastate the region. ${ }^{28}$ To this end, an independent and flexible regional currency makes theoretical sense, but is unlikely to develop under current conditions.

On the surface the economic and political challenges make monetary convergence seem an insurmountable task, but the same was said when the idea of the Euro was first floated. What is 
encouraging is the aspirational nature of the vision for a common currency union which represents a starting point for discussions and compromise. To be sure, there is a long road ahead for both visions of the Eco. ${ }^{29}$ Such ructions are not out of the ordinary for a task of this magnitude, but the danger of spill over into already agreed pacts like AfCFTA is real and should not be dismissed. ${ }^{30}$

WAEMU states will soon have to show their hand, and side with their former colonial master, or join their African counterparts where they risk being vastly overshadowed by a much larger and more powerful country in Nigeria. The next few months ahead of the proposed July launch of the WAEMU Eco will be telling and infighting may well delay the eventual rollout.

\section{Conclusion}

For now, the shift from the CFA franc to the Eco appears to be designed for positive optics, for both France and WAEMU countries, and more political than economic. It is a move that reduces the perception of France as a persistent colonial presence in its former colonies, while at the same time providing political capital to incumbent presidents who can be seen shaking loose the shackles of their oppressors.

There are nonetheless a myriad of potential outcomes from the endeavour, many positive but some overwhelmingly negative, and any eventual fallout could be felt across the continent, amongst citizens and businesses, on a social and political level. There is still uncertainty (even among members) as to how the new Eco (or even which version) will ultimately be rolled out, but the decision to renegotiate the terms of CFA participation among WAEMU countries will be keenly watched by fellow CFA members in central Africa.

What is certain, is that it is far too early either to celebrate or to be concerned. The efficacy of the new model will take time to unfurl, and for citizens and businesses, it will be business as usual - at least for now.

Author: Ronak Gopaldas

Editor: Dr. A. Lee Gilbert

Editor-in-chief: Prof. Sam Park 


\section{References}

${ }^{1}$ Benin, Burkina Faso, Cote-d'Ivoire, Guinea-Bissau, Mali, Niger, Senegal, Togo

${ }^{2}$ Gambia, Ghana, Guinea, Liberia, Nigeria and Sierra Leone

${ }^{3} \mathrm{DW}$. West African states mired in controversy over 'Eco' currency. DW. [Online] January 18, 2020.

https://www.dw.com/en/west-african-states-mired-in-controversy-over-eco-currency/a-52045052.

${ }^{4}$ 18. African Business. A brief History of the FCA Franc. African Business Magazine. [Online] February 19, 2012.

http://africanbusinessmagazine.com/uncategorised/a-brief-history-of-the-cfa-franc/.

${ }^{5}$ Arab News. West African opinion divided over CFA franc reform. Arab News. [Online] December 25, 2019.

https://www.arabnews.com/node/1603646/business-economy.

${ }^{6}$ The Economist. Francophone Africa's CFA franc is under fire. The Economist. [Online] January 27, 2018.

https://www.economist.com/middle-east-and-africa/2018/01/27/francophone-africas-cfa-franc-is-under-fire.

${ }^{7}$ Daily Trust. Why France kidnapped West Africa's Eco currency. Daily Trust. [Online] December 27, 2019.

https://www.dailytrust.com.ng/why-france-kidnapped-west-africas-eco-currency.html

${ }^{8}$ Africa News. From CFA franc to Eco: evolution of a controversial currency. Africa News. [Online] December 24, 2019.

https://www.africanews.com/2019/12/24/from-cfa-franc-to-eco-inside-the-evolution-of-a-controversial-currency//

${ }_{9}^{9}$ MacDougall, Clair. A pan-African CFA activist is the face of rising anti-French sentiment in Francophone West Africa. Quartz

Africa. [Online] January 9, 2020. https://qz.com/africa/1781660/france-the-end-of-west-africas-cfa-kemi-seba-and-eco/.

${ }^{10} \mathrm{CNN}$. France is set to end the use of the 75-year-old controversial CFA franc in West Africa. CNN. [Online] December 23,

2019. https://edition.cnn.com/2019/12/23/africa/france-stops-use-of-cfa/index.html

${ }^{11}$ Specia, Megan. The African Currency at the Center of a European Dispute. The New York Times. [Online] January $22,2019$. https://www.nytimes.com/2019/01/22/world/africa/africa-cfa-franc-currency.html

${ }^{12}$ Africa News. From CFA franc to Eco: evolution of a controversial currency. Africa News. [Online] December 24, 2019.

https://www.africanews.com/2019/12/24/from-cfa-franc-to-eco-inside-the-evolution-of-a-controversial-currency//.

${ }_{13}$ Diagne, Cheikh Ahmed Bamba. Why abandoning the CFA Franc would be a risky operation. The Conversation. [Online] July

21, 2019. https://theconversation.com/why-abandoning-the-cfa-franc-would-be-a-risky-operation-120551

${ }_{14}$ IMF. Report for Selected Countries and Subjects. IMF. [Online] October 2019.

https://www.imf.org/external/pubs/ft/weo/2019/02/weodata/weorept.aspx?sy=2000\&ey=2024\&scsm=1\&ssd=1\&sort=subject\&ds $=\% 2 \mathrm{C} \& \mathrm{br}=1 \& \mathrm{pr} 1 . \mathrm{x}=38 \& \mathrm{pr} 1 . \mathrm{y}=11 \& \mathrm{c}=614 \% 2 \mathrm{C} 666 \% 2 \mathrm{C} 638 \% 2 \mathrm{C} 668 \% 2 \mathrm{C} 616 \% 2 \mathrm{C} 674 \% 2 \mathrm{C} 748 \% 2 \mathrm{C} 676 \% 2 \mathrm{C} 618 \% 2 \mathrm{C} 678 \% 2 \mathrm{C} 624$ \%2C684\%2C622\%2C688\%2C626\%2C728\%2C628\%2C692\%2C632

${ }^{15}$ Coppola, Frances. In Africa: Understanding the CFA Franc and its Foreign Exchange Rate Impact. American Express.

[Online] 2018. https://www.americanexpress.com/us/foreign-exchange/articles/cfa-franc-and-its-foreign-exchange-rate-impact/

${ }^{16}$ DW. The CFA franc in West Africa: Time for a change? DW. [Online] December 22, 2018. https://www.dw.com/en/the-cfa-

franc-in-west-africa-time-for-a-change/a-44348656

${ }_{17}$ Coulibaly, Issiaka. COSTS AND BENEFITS OF THE CFA FRANC. World Policy. [Online] February 28, 2017.

https://worldpolicy.org/2017/02/28/costs-and-benefits-of-the-cfa-franc/

${ }_{18}$ IMF. Report for Selected Countries and Subjects. IMF. [Online] October 2019.

https://www.imf.org/external/pubs/ft/weo/2019/02/weodata/weorept.aspx?sy=2000\&ey=2024\&scsm=1\&ssd=1\&sort=subject\&ds $=\% 2 \mathrm{C} \& \mathrm{br}=1 \& \mathrm{pr} 1 . \mathrm{X}=38 \& \mathrm{pr} 1 . \mathrm{y}=11 \& \mathrm{c}=614 \% 2 \mathrm{C} 666 \% 2 \mathrm{C} 638 \% 2 \mathrm{C} 668 \% 2 \mathrm{C} 616 \% 2 \mathrm{C} 674 \% 2 \mathrm{C} 748 \% 2 \mathrm{C} 676 \% 2 \mathrm{C} 618 \% 2 \mathrm{C} 678 \% 2 \mathrm{C} 624$ $\% 2 \mathrm{C} 684 \% 2 \mathrm{C} 622 \% 2 \mathrm{C} 688 \% 2 \mathrm{C} 626 \% 2 \mathrm{C} 728 \% 2 \mathrm{C} 628 \% 2 \mathrm{C} 692 \% 2 \mathrm{C} 632$

${ }^{19}$ Allison, Simon. The gilded cage: Who does the CFA franc really benefit? How We Made it in Africa. [Online] April 10, 2015. https://www.howwemadeitinafrica.com/the-gilded-cage-who-does-the-cfa-franc-really-benefit/48152/

${ }^{20}$ IMF. Report for Selected Countries and Subjects. IMF. [Online] October 2019.

https://www.imf.org/external/pubs/ft/weo/2019/02/weodata/weorept.aspx?sy=2000\&ey=2024\&scsm=1\&ssd=1\&sort=subject\&ds $=\% 2 \mathrm{C} \& \mathrm{br}=1 \& \mathrm{pr} 1 . \mathrm{x}=38 \& \mathrm{pr} 1 . \mathrm{y}=11 \& \mathrm{c}=614 \% 2 \mathrm{C} 666 \% 2 \mathrm{C} 638 \% 2 \mathrm{C} 668 \% 2 \mathrm{C} 616 \% 2 \mathrm{C} 674 \% 2 \mathrm{C} 748 \% 2 \mathrm{C} 676 \% 2 \mathrm{C} 618 \% 2 \mathrm{C} 678 \% 2 \mathrm{C} 624$ $\% 2 \mathrm{C} 684 \% 2 \mathrm{C} 622 \% 2 \mathrm{C} 688 \% 2 \mathrm{C} 626 \% 2 \mathrm{C} 728 \% 2 \mathrm{C} 628 \% 2 \mathrm{C} 692 \% 2 \mathrm{C} 632$

${ }_{21}$ DW. Africa's CFA franc - colonial relic or stabilizing force? DW. [Online] May 27, 2019. https://www.dw.com/en/africas-cfafranc-colonial-relic-or-stabilizing-force/a-48908889

22 Diagne, Cheikh Ahmed Bamba. Why abandoning the CFA Franc would be a risky operation. The Conversation. [Online] July 21, 2019. https://theconversation.com/why-abandoning-the-cfa-franc-would-be-a-risky-operation-120551

${ }^{23}$ Gambia, Ghana, Guinea, Nigeria and Sierra Leone

${ }^{24}$ Aboa, Ange. West Africa renames CFA franc but keeps it pegged to euro. Reuters. [Online] December 21, 2019.

https://www.reuters.com/article/us-ivorycoast-france-macron/west-africa-renames-cfa-franc-but-keeps-it-pegged-to-euroidUSKBN1YP0JR

${ }^{25}$ Africa News. Nigeria leads 6 nations opposed to change of CFA franc to Eco. Africa News. [Online] January 17, 2020.

https://www.africanews.com/2020/01/17/nigeria-leads-6-nations-opposed-to-change-of-cfa-franc-to-eco//

${ }_{26}$ Africa News. From CFA franc to Eco: evolution of a controversial currency. Africa News. [Online] December 24, 2019.

https://www.africanews.com/2019/12/24/from-cfa-franc-to-eco-inside-the-evolution-of-a-controversial-currency//

${ }^{27}$ African Business. A brief History of the FCA Franc. African Business Magazine. [Online] February 19, 2012.

http://africanbusinessmagazine.com/uncategorised/a-brief-history-of-the-cfa-franc/

${ }^{28}$ Faujas, Alain. Unpacking West Africa's transition to the Eco. The Africa Report. [Online] , January 6, 2020.

https://www.theafricareport.com/21806/unpacking-west-africas-transition-to-the-eco/

${ }^{29}$ London School of Economics. The CFA Franc: French Monetary Imperialism in Africa. London School of Economics. [Online] July 12, 2017. https://blogs.Ise.ac.uk/africaatlse/2017/07/12/the-cfa-franc-french-monetary-imperialism-in-africa/

30 The East African. Does French-backed CFA franc keep some African countries poor? The East African. [Online] January 25 ,

2019. https://www.theeastafrican.co.ke/news/africa/CFA-franc-France-Africa-controversy/4552902-4950882-r08s4t/index.html 


\section{NTU-SBF Centre for African Studies}

The NTU-SBF Centre for African Studies (CAS) is to develop thought leadership and capacity for doing business in Africa. It includes bringing Africa to Southeast Asia and Singapore and helping Singapore to be positioned as the gateway into Southeast Asia. As such, CAS aims to build and expand its local and international profile by means of publications, conferences, seminars and business forums through collaboration with local businesses, other research entities and business schools in Singapore and Africa. http://www.nbs.ntu.edu.sg/Research/ResearchCentres/CAS
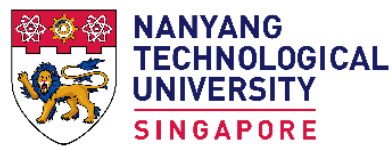

\section{Nanyang Centre for Emerging Markets}

The Nanyang Centre for Emerging Markets (CEM) is a new initiative by Nanyang Business School to establish global thought leadership on business-related issues in emerging markets. It conducts research on pressing and timely business issues in emerging markets through a global research platform of leading scholars and institutional partners. It closely interacts with corporate partners to identify research topics and manage the research process. Its research outputs include valuable and relevant implications for sustained profitable growth for local and multinational companies in emerging markets. It delivers a variety of research reports and organizes forums, seminars, CEO roundtables, conferences, and executive training programmes for broad dissemination of its research outputs.

http://www.nbs.ntu.edu.sg/Research/ResearchCentres/CEM

\section{Partner Organizations}

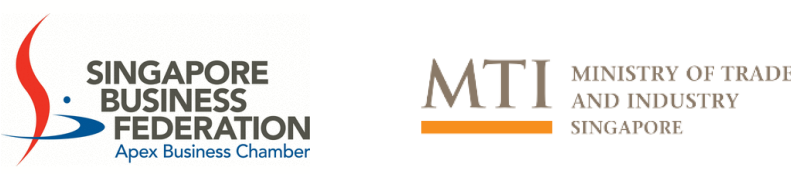

Enterprise

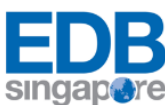

INDORAMA
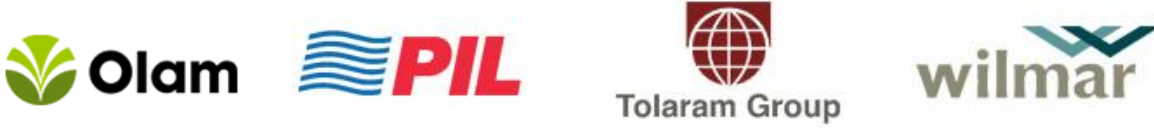

\section{Contact Information:}

Que Boxi

Email: cas@ntu.edu.sg

Phone: +65 65138089

Address: S3-B1A-35 Nanyang Business School

Nanyang Technological University

50 Nanyang Avenue Singapore 639798 